\title{
The Khos-Nelege section of the Ogon'or Formation: a potential candidate for the GSSP of Stage 10, Cambrian System
}

\author{
Nadezhda P. lazarenko, ivan Y. Gogin, Tatyana V. Pegel \& Galina P. Abaimova
}

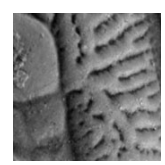

\begin{abstract}
The International Subcommission on Cambrian Stratigraphy (ISCS) has recommended a subdivision of the Cambrian System into four series and ten stages. The first appearance datum (FAD) of the cosmopolitan agnostoid trilobite Lotagnostus americanus has been chosen as a good indicator for the base of the uppermost Cambrian stage (Stage 10). The Khos-Nelege section located in the north-eastern Siberian Platform (Western Yakutia, Russia) is proposed as the Global Standard Stratotype Section and Point (GSSP) for the base of the 'Cambrian Stage 10'. The proposed GSSP coincides with the FAD of L. americanus at $339 \mathrm{~m}$ above the base of the Ogon'or Formation. The section fulfills the geological and biostratigraphical requirements for a stratotype and the GSSP horizon can be constrained by a number of auxiliary marker taxa. The first appearance of L. americanus is an easily recognizable level in the Cambrian which can be recognized from all major Cambrian continents, including Baltica, Laurentia, Avalonia, South China and Australia. - Key word: Cambrian, Stage 10, trilobite, GSSP, Lotagnostus americanus, Russia.
\end{abstract}

LaZarenko, N.P., Gogin, I.Y., Pegel, T.V. \& Abaimova, G.P. 2011. The Khos-Nelege River section of the Ogon'or Formation: a potential candidate for the GSSP of Stage 10, Cambrian System. Bulletin of Geosciences 86(3), 555-568 (12 figures). Czech Geological Survey. Prague, ISSN 1214-1119. Manuscript received January 1, 2011; accepted in revised form July 6, 2011; published online September 19, 2011; issued September 30, 2011.

Nadezhda P. Lazarenko, State Enterprise All-Russia Research Institute for Geology and Mineral Resources of the World Ocean, 1 Angliyskiy Prospect, St. Petersburg, 199121, Russia •Ivan Y. Gogin, Russian Geological Research Institute, 74 Sredny Prospect, St. Petersburg, 199106, Russia; Ivan_Gogin@vsegei.ru・Tatyana V. Pegel (corresponding author) \& Galina P. Abaimova, Siberian Research Institute of Geology, Geophysics and Mineral Resources, 67 Krasny Prospect, Novosibirsk,630091,Russia; pegel@mail.ru,pegel@sniiggims.ru; abaimovagp@yandex.ru

Subdivision of the Cambrian System into series and stages that can be applicable in a global scale is among major objectives of the International Subcommission on Cambrian Stratigraphy (ISCS) for a number of years. The absence of internationally recognized global standard for the Cambrian System partly a consequence of different stratigraphical approach developed historically by researches working in different regions, but also reflects faunal provincialism resulted the scarcity of suitable biostratigraphical markers applicable for intercontinental correlation at the Stage level. However, current progress in research on Cambrian trilobite biostratigraphy in combination with chemostratigraphy improved significantly long-range correlation of the regional Cambrian chronostratigraphic units (Babcock et al. 2005).

The ISCS came to the conclusion that the Cambrian System subdivision into four series and ten stages, looks as the most practical strategy (Babcock et al. 2005). So far, only four stages have been formally named and formally approved by the Commission on Stratigraphy IUGS. These are the Fortunian Stage (= base of Terreneuvian Series and Cambrian System), the Drumian Stage, Guzhangian Stage and the Paibian Stage (= base of Furongian Series). Apart from the Paibian, the two succeeding stages (Cambrian Stage 9 and 10) in the Furongian Series remain to be defined. In addition, in 2010, Duibian B section in Zhejiang, China was chosen by the ISCI as GSSP for the base of the Cambrian Stage 9 (= Jiangshanian Stage) defined by the FAD of the agnostoid trilobite Agnostotes orientalis. However, this decision is still awaiting ratification from the Commission on Stratigraphy IUGS. Babcock et al. (2005) suggested that the FAD of the agnostoid trilobite Lotagnostus americanus, may be the best choice for defining the base of the Cambrian Stage 10, which is the only Furongian Stage remaind awaiting for formal designation (Fig. 1).

The main objective of this paper is to present updated and refined documentation for a stratigraphic sequence through the upper part of the Furongian Series in the KhosNelege section which is presented as a GSSP candidate for 


\begin{tabular}{|c|c|c|c|}
\hline SYSTEMS & SERIES & STAGES & $\begin{array}{l}\text { Ratified (GSSPs) and } \\
\text { suggested chronostrati- } \\
\text { graphic level }\end{array}$ \\
\hline Ordovician & Lower & Tremadocian & \multirow{7}{*}{$\begin{array}{l}\text { FAD of lapetognathus } \\
\text { fluctivagus (GSSP) } \\
\text { FAD of Lotagnostus } \\
\text { americanus: } \\
\text { proposed GSSP position } \\
\text { FAD of Agnostotes } \\
\text { orientalis: } \\
\text { proposed GSSP position } \\
\text { FAD of Glyptagnostus } \\
\text { reticulatus (GSSP) } \\
\text { FAD of Lejopyge laevigata } \\
\text { (GSSP) } \\
\text { FAD of Ptychagnostus } \\
\text { atavus (GSSP) }\end{array}$} \\
\hline \multirow{10}{*}{ 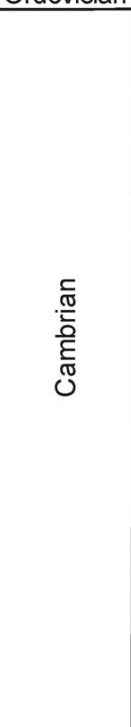 } & \multirow{3}{*}{ Furongian } & Stage 10 & \\
\hline & & Stage 9 & \\
\hline & & Paibian & \\
\hline & \multirow{3}{*}{$\begin{array}{c}\text { Series } 3 \\
\text { (Undefined) }\end{array}$} & Guzhangian & \\
\hline & & Drumian & \\
\hline & & $\begin{array}{l}\text { Stage } 5 \\
\text { (Undefined) }\end{array}$ & \\
\hline & \multirow{2}{*}{$\begin{array}{c}\text { Series } 2 \\
\text { (Undefined) }\end{array}$} & $\begin{array}{c}\text { Stage } 4 \\
\text { (Undefined) }\end{array}$ & \multirow{2}{*}{$\begin{array}{l}\text { ? FADs of Ovatoryctocara } \\
\text { granulata or Oryctocepha- } \\
\text { lus indicus: proposed } \\
\text { GSSPs positions } \\
\text { ?FAD of Olenellus or } \\
\text { Redlichia }\end{array}$} \\
\hline & & $\begin{array}{c}\text { Stage } 3 \\
\text { (Undefined) }\end{array}$ & \\
\hline & \multirow{2}{*}{ Terreneuvian } & $\begin{array}{c}\text { Stage 2 } \\
\text { (Undefined) }\end{array}$ & \multirow{3}{*}{$\begin{array}{l}\text { FAD of trilobites } \\
\text { ?FAD of SSF or archaeo- } \\
\text { cyathid species } \\
\text { FAD of Trichophycus } \\
\text { pedum (GSSP) }\end{array}$} \\
\hline & & Fortunian & \\
\hline \multicolumn{3}{|l|}{ Ediacaran } & \\
\hline
\end{tabular}

Figure 1. Chart showing working model for the global chronostratigraphical subdivision of the Cambrian System, indicating the position of the Cambrian Stage 10 and its lower boundary (modified from Babcock et al. 2005).

designation of the Cambrian System 'Tenth' Stage, defined by the FAD of the agnostoid trilobite Lotagnostus americanus.

\section{Motivation for selection of the boundary level and of the potential stratotype section}

Lotagnostus (Lotagnostus) americanus (Billings) is easily recognizable agnostoid taxon, which was recently revised by Peng \& Babcock (2005). It was demonstrated that a number of species, including Lotagnostus asiaticus Troedsson, L. xinjiangensis Zhang, L. punctatus Lu, L. trisectus (Salter), L. obscurus Palmer and Goniagnostus verrucosus Rusconi represent junior objective synonyms of Lotagnostus americanus, thus presently this trilobite species is documented from almost all major Cambrian paleocontinents, which makes it a valuable tool for global correlation.

The diagnostic characteristics of Lotagnostus americanus include: lengthwise partition of the axis into three parts; pleurae with distinct scrobiculae; cephalon with a narrow roll-shaped border; a pentagonal anterior glabellar lobe; F3 curved backwards; node on the main glabellar lobe occupying the most elevated part of the cephalon; elongated basal lobes; presence of a preglabellar furrow; a long pygidial axis; medially effaced F1; broad border furrow; and presence of posterolateral marginal spines. Based on these criteria, L. obscurus Palmer should be excluded from the synonymy of L. americanus, because it has a nonscrobiculate surface and a short pygidial axis with a rounded posterior termination. This suggests that Lotagnostus obscurus has the closest affinity to the subgenus Lotagnostus (Eolotagnostus) Zhou.

Lotagnostus americanus has a short stratigraphic range in the late Furongian and is a common taxon in the open shelf lithofacies (Peng \& Babcock 2005 and references therein) (Fig. 2).

Presently, occurrences of L. americanus are documented from Quebec, Newfoundland, Precordilleran Argentina, Sweden, China, Kazakhstan (Malyi Karatau), Kyrgyzstan (north Tien Shan), Australia, Avalonia (England and Wales), and Siberia (Babcock et al. 2005, Geyer \& Shergold 2000, Peng \& Babcock 2005, Peng et al. 2005) and it can be identified with precision using multiple lines of evidence. Lotagnostus americanus is widely used as the index taxon in Siberia, China and Scandinavia (Lazarenko et al. 2008, Peng \& Babcock 2005, Terfelt et al. 2008). The early representatives of Lotagnostus emerged at the time, when Eurudagnostus and Oncagnostus (Oncagnostus) went into extinction or were in terminal decline, and the agnostoid genus Trilobagnostus had just appeared (Ergaliev \& Ergaliev 2008, Terfelt et al. 2011, Lazarenko et al. 2008).

Lotagnostus (Lotagnostus) americanus occupied an intermediate position in the evolution of Lotagnostus. Species of Lotagnostus (Eolotagnostus), which differ in having poorly scrobiculate cephalic pleurae (sometimes pygidial pleurae too) and a rounded posterior termination of a relatively short pygidial axis, appeared earlier in the sequence than the first representatives of Lotagnostus (Lotagnostus) and Lotagnostus (Distagnostus). For instance in China Lotagnostus (Eolotagnostus) occurs at the Furrongian Lotagnostus (Eolotagnostus) decorus-Kaolishaniella Biozone and Probilacunaspis nasalis-Peichiashania chunanensis Biozone (Peng 1992), whereas in Kazakhstan (Malyi Karatau) it is documented from the Lotagnostus (Eolotagnostus) scrobicularis-Jegorovaia Biozone (upper Aksayan Regional Stage) (Ergaliev \& Ergaliev 2008).

The evolutionary lineage of the genus Lotagnostus terminated with L. hedini, which is the index-species of a biozone designated for the uppermost Furongian in China (West Zheijang, Peng 1992) and in Kazakhstan (upper part of Batyrbaian Regional Stage of Malyi and Bolshoi Karatau ranges) (Ergaliev \& Ergaliev 2008). In the Batyrbai section of the Malyi Karatau Range, Kazakhstan, Lotagnostus hedini occurs in the upper part of the Proconodontus notchpeakensis conodont zone (Apollonov \& Chugaeva 1983). In the Dadoushen section, Duibian, China, Lotagnostus hedini occurs together with the conodonts Eoconodontus notchpeakensis and Cordylodus proavus. 
Nadezhda P. Lazarenko et al. • A potential candidate for the GSSP of Stage 10 in Siberia

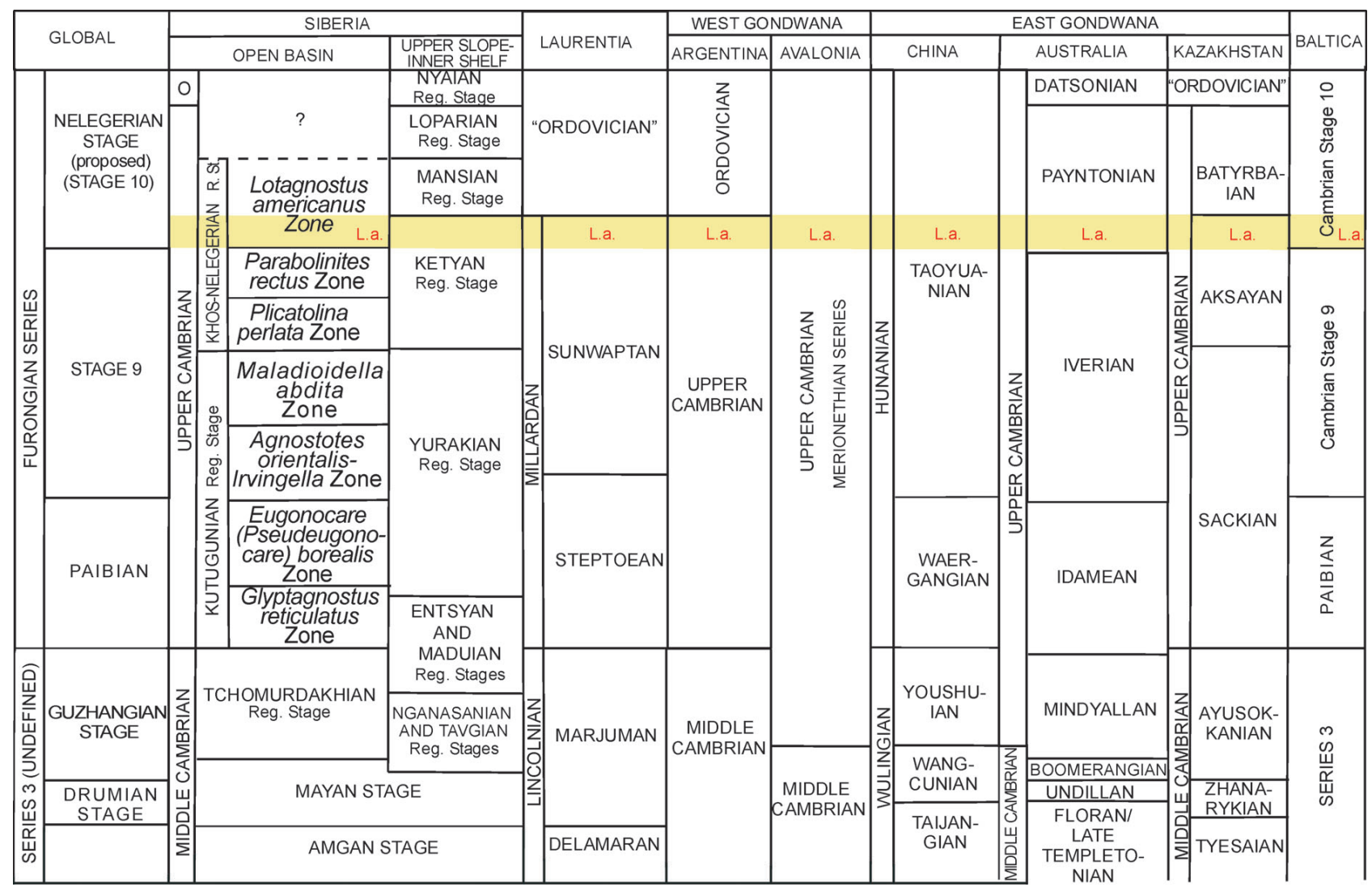

Figure 2. Correlation chart of the upper part of the Cambrian showing the global Cambrian stages compared to regional usage in major areas of the world. The presence of Lotagnostus americanus in a region is indicated by symbol L.a. Chart is compiled from numerous sources, summarized principally in Geyer \& Shergold (2000) and Peng et al. (2004).

In the same area, the species Lotagnostus americanus (= L. punctatus) is common in underlying strata $(\mathrm{Lu} \& \mathrm{Lin}$ 1989).

The global correlation of the FAD of L. americanus is supported by data on the polymerid trilobites. In Scandinavia, Lotagnostus americanus ranges through the Ctenopyge tumida, C. affinis, C. bisulcata and C. linnarssoni biozones, which are correlated with the L. americanus to lower Trilobagnostus holmi agnostoid biozones (Terfelt et al. 2008, 2011). In South China, L. americanus is characteristic for the L. americanus (= L. punctatus) Biozone and L. americanus $(=$ L. punctatus $)-$ Hedinaspis regalis Biozone $(\mathrm{Lu}$ $\&$ Lin 1989, Peng 1992). The first occurrence of the polymerid trilobites Ctenopyge (Mesoctenopyge), Macropyge, Peltura in Scandinavia (Terfelt et al. 2011), Promegalaspides, Skljarella in Western Yakutia, Russia (Lazarenko et al. 2008), Saukia, Niobella, Hedinaspis, Skljarella in Kazakhstan (Ergaliev 1983, Ergaliev \& Ergaliev 2008), Niobella, Hedinaspis, Skljarella in China (Peng 1992) was documented close to the FAD of L. americanus.

The Cambrian sections of the Tuora-Sis Ridge represent a part of the Siberian platform carbonate cover, formed in the large Yudoma-Olenek Basin. The basin is contured by thick reef deposites in its western and northern margins. Significant depths and uniform sedimentational settings of basin and deep ramp characterized the region in the Middle-terminal Late Cambrian. Selection of a GSSP in the basis of slope deposit from low palaeolatitudes such as the Siberian Platform, is desirable because it allows correlation with strata deposited in both open-shelf and basinal areas of low or high palaeolatitudes. Slope areas are characterized by a combination of shelf-dwelling taxa and basindwelling taxa. A combination of cosmopolitan agnostoids (which have intercontinental correlation utility) shelf-dwelling polymerids (which mostly allow for intracontinental correlation) and pan-tropical polymerids (which allow for limited intercontinental correlation), constitute a tool box facilitating precise correlation of the base of the Lotagnostus americanus Zone between Siberia, South China, Gondwana, Laurentia, Baltica, and the Kazakh terranes.

\section{Potential stratotype section}

Selection of the the Khos-Nelege section as the potential GSSP for the base of the Cambrian Stage 10 is well supported by the analysis of new and previously accumulated data on the palaeontology and biostratigraphy of the Furongian 


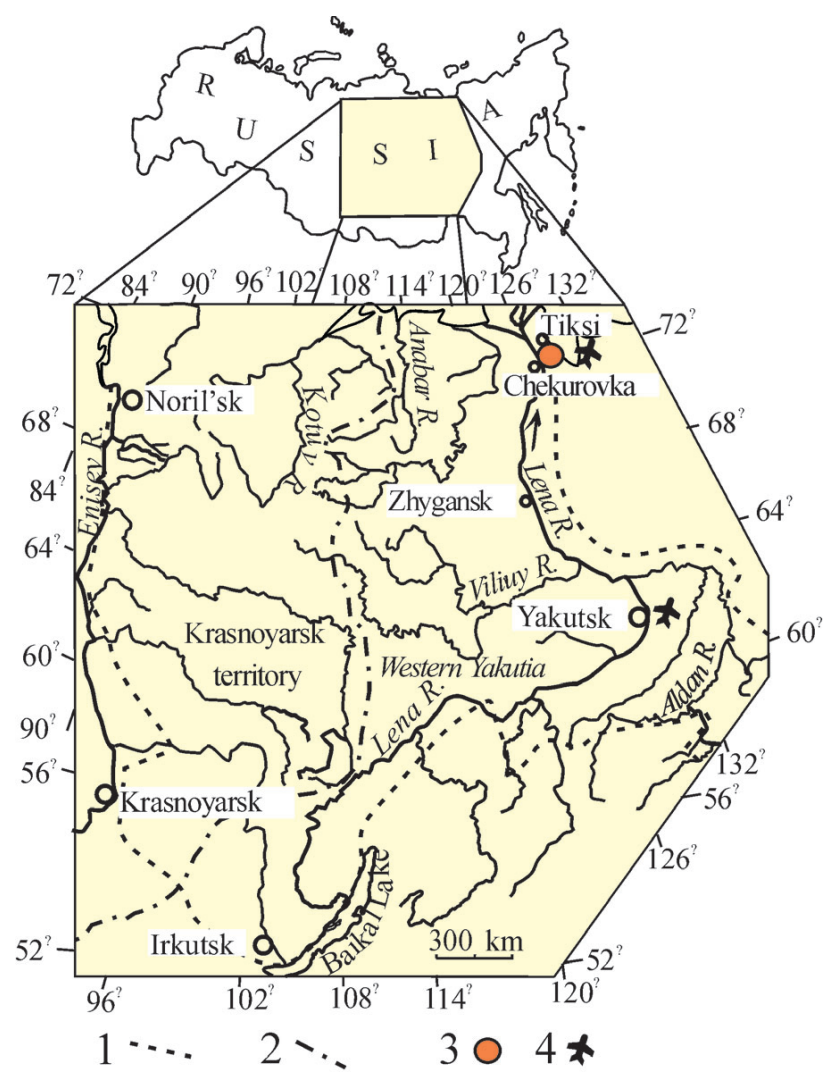

Figure 3. Location map of the Siberian Platform showing the position of the Khos-Nelege reference section. 1 - the Siberian Platform boundary; 2 - the boundary between Krasnoyarsk territory and Western Yakutia; 3 - the Khos-Nelege reference section (from Lazarenko et al. 2008), 4 - the airports.

deposits across the northeastern Siberian Platform (e.g. Lazarenko 1966, 1973; Lazarenko et al. 2008; Lazarenko \& Nikiforov 1972; Lazarenko \& Pegel 2001).

The Khos-Nelege section is located in the Lower Lena River basin, at approximately $25 \mathrm{~km}$ north-east of the Chekurovka village and at about $60 \mathrm{~km}$ south-west of the town Tiksi in north-west Yakutia, Russia (Fig. 3). It can be reached by helicopter from Tiksi in twenty minutes. The Khos-Nelege River is part of the Neleger River system, which is a confluent to the Lena River (Figs 4, 5). The Neleger River dissects the Tuora-Sis Ridge (northeastern part of the Verkhoyansk Ridge) from the east to the west. The section is located on a public land under permanent protection by the government of the Republic of Sakha (Yakutia). This will ensure unrestricted free access to the site for research purposes.

The Ogon' or Formation in the Khos-Nelege section is a thick, mostly monotonous succession of rhythmically alternating limestones, calcareous argillites and fine siliciclastic sediments deposited in a distal slope environment (outer fan to basin transition). The strata strike at about $295-305^{\circ}$ and dip at about $55-60^{\circ}$. Soft-sediment de-

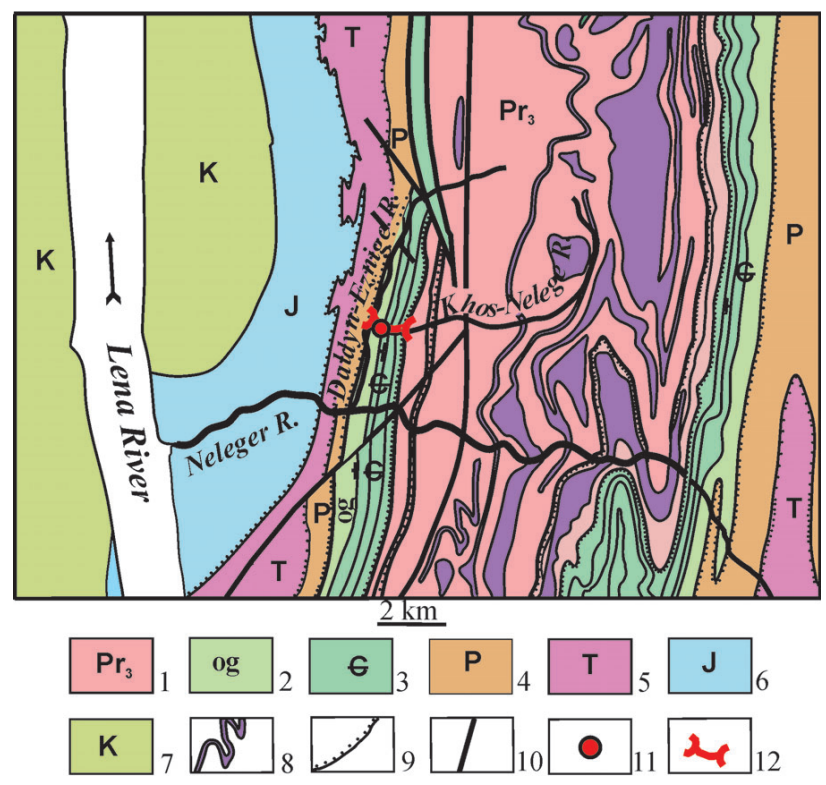

Figure 4. Geological map and location of the section proposed as a stratotype for the Nelegerian Stage lower boundary (the Khos-Nelege reference section, Western Yakutia, Russia). 1 - Upper Proterozoic; 2 - upper part of the Cambrian, Ogon'or Formation; 3 - middle and lower part of the Cambrian; 4 - Permian; 5 - Triassic; 6 - Jurassic; 7 - Cretaceous; 8 - sills of basic rocks; 9 - disconformity; 10 -tectonic disturbances; 11 -stratotype section; 12 - the reference section of the Cambrian open basinal deposits along the Khos-Nelege River (from Lazarenko et al. 2008).

formation, truncation surfaces and slide surfaces are rare throughout the section and absent near the proposed GSSP. The proposed GSSP position for the base of the Cambrian Stage 10 defined by the FAD of L. americanus, is at $339 \mathrm{~m}$ above the base of the Ogon' or Formation (Figs 6, 7). This level is within a continuous succession of foliated silty mudstones with thin lenticular limestone interbeds.

\section{Trilobite biostratigraphy}

Trilobite biostratigraphy of the Ogon' or Formation in the measured section (Figs 6,8) exhibits a complete, tectonically undisturbed marine succession from the uppermost part of the Drumian Stage (the lowermost $10 \mathrm{~m}$ of the Ogon'or Formation below the base of the Lejopyge laevigata Biozone) and up to the Cambrian Stage 10 (Nelegerian Stage of Lazarenko et al. 2008) marked by the FAD of L. americanus.

Specimens of L. americanus were sampled from at least 21 horizons over the interval almost $90 \mathrm{~m}$ thick in the Khos-Nelege section (at $339 \mathrm{~m}, 349 \mathrm{~m}, 357 \mathrm{~m}, 362.2 \mathrm{~m}$, $362.6 \mathrm{~m}, 366.3 \mathrm{~m}, 368.3 \mathrm{~m}, 369 \mathrm{~m}, 370.3 \mathrm{~m}, 370.7 \mathrm{~m}$, $374.4 \mathrm{~m}, 375.3 \mathrm{~m}, 382 \mathrm{~m}, 382.15 \mathrm{~m}, 384 \mathrm{~m}, 393.35 \mathrm{~m}$, $395 \mathrm{~m}, 391.7 \mathrm{~m}, 401.7 \mathrm{~m}, 421.35 \mathrm{~m}$ and $421.4 \mathrm{~m}$ above the base of the Ogon'or Formation, respectively). At the lowest $10 \mathrm{~m}$ of the sampled interval $(339 \mathrm{~m}$ and $349 \mathrm{~m}$ ) 


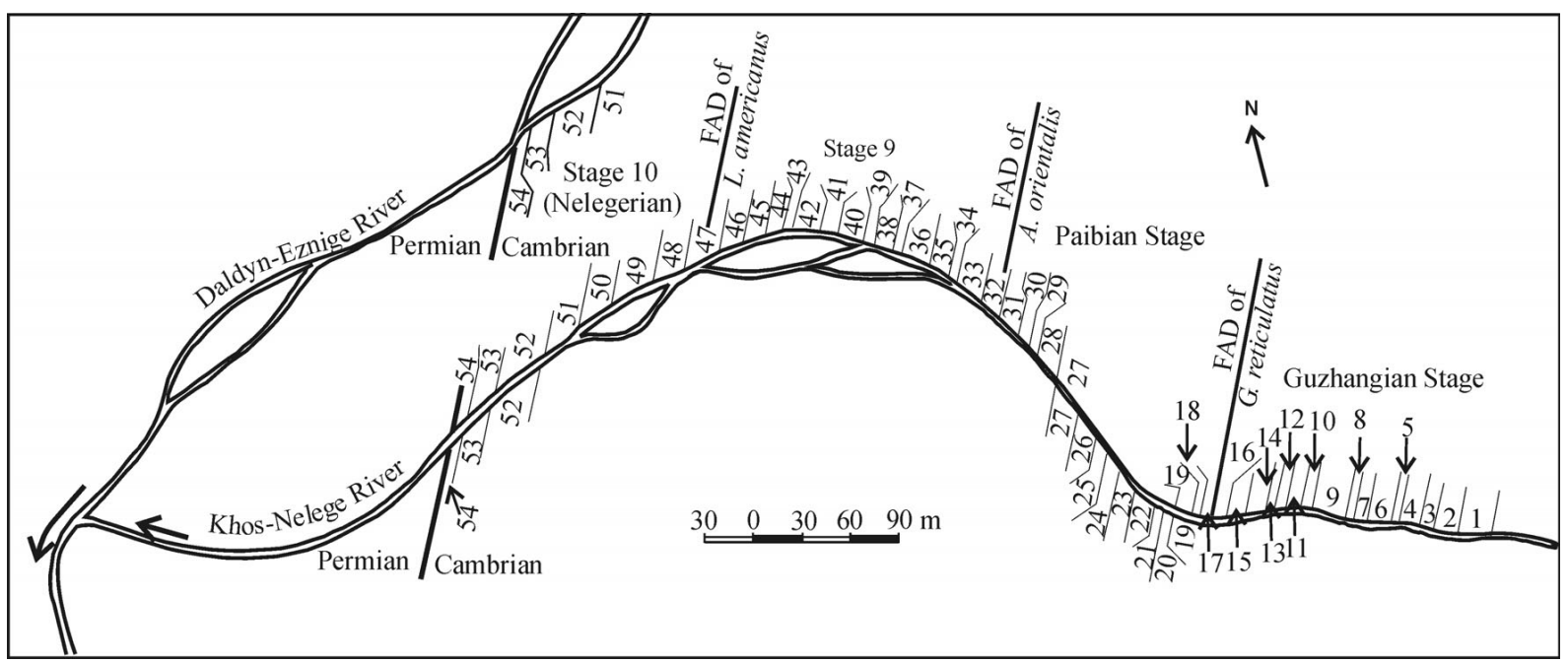

Figure 5. Position of global correlative levels of the Furongian Series and Proposed GSSP for the base of the Stage 10 (Nelegerian) (coinciding with the FAD of Lotagnostus americanus) in the beds of the Ogon'or Formation in the Khos-Nelege section (modified from Lazarenko et al. 2008).

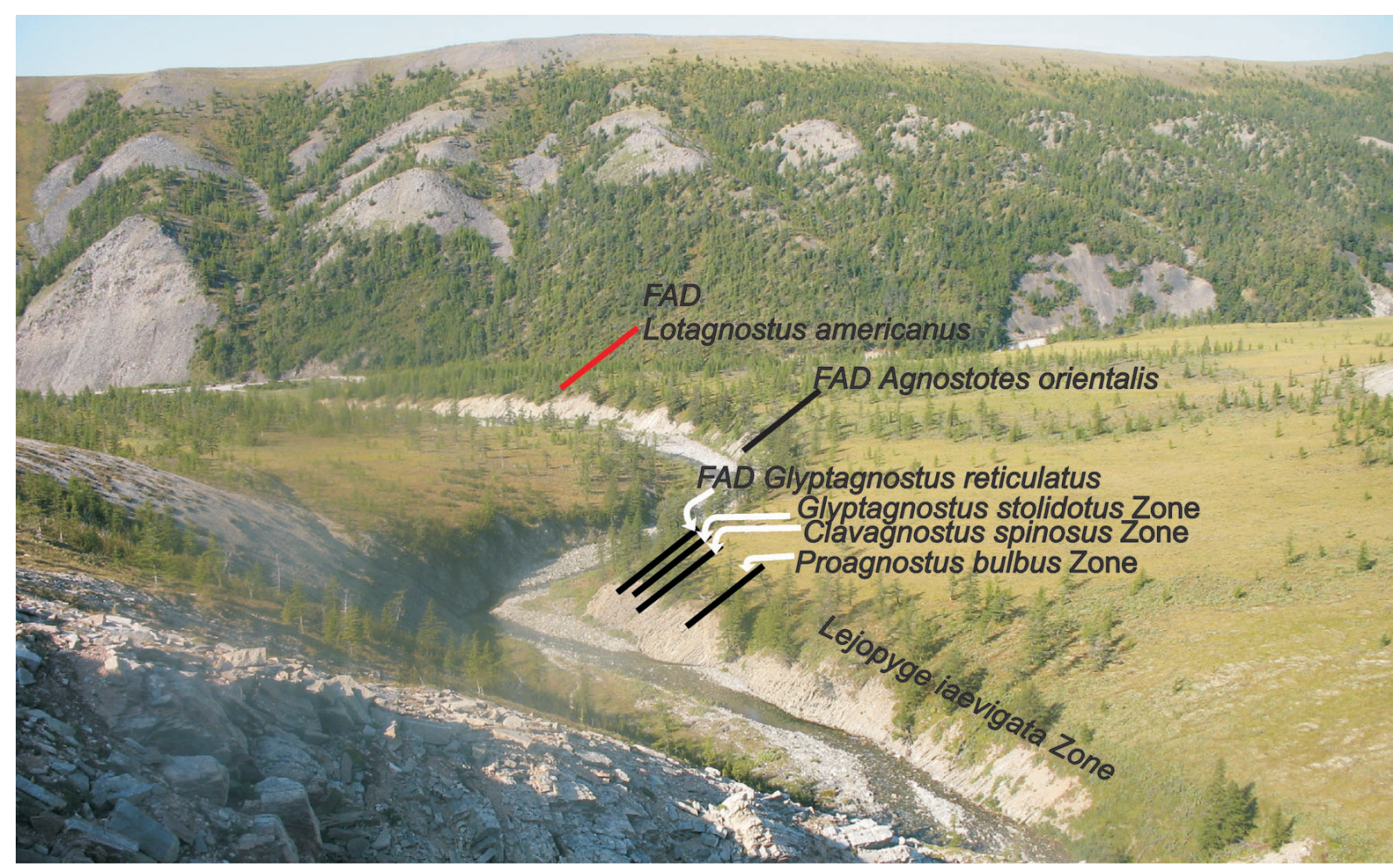

Figure 6. View of the right bank of the Khos-Nelege River showing deposits of the Ogon'or Formation with proposed GSSP for the base of the Nelegerian Stage (coinciding with the FAD of Lotagnostus americanus). Underlying sediments are compared with Stage 9 (which base coincides with the FAD of Agnostotes orientalis), the global Paibian Stage (which base coincides with the FAD of Glyptagnostus reticulatus), and the Guzhangian Stage (which base coincides with the FAD of Lejopyge laevigata) (from Lazarenko et al. 2008).

L. americanus is relatively rare. Numerous disarticulated cephala and pygidia of the species occur at: $357 \mathrm{~m}$, $362.2 \mathrm{~m}, 370.3 \mathrm{~m}, 375.3 \mathrm{~m}, 382.15 \mathrm{~m}, 391.7 \mathrm{~m}$ and $421.35 \mathrm{~m}$, respectively. A complete range of L. americanus cannot be determined at Khos-Nelege, because the top of the section is cut by the unconformity.
Observed ranges of agnostoids and polymerid trilobites across the stratigraphical interval including the proposed GSSP are summarized in Fig. 8. The new material, obtained from the Ogon' or Formation in the Khos-Nelege section together with a comprehensive revision of previously assembled collections revealed that the specimens 


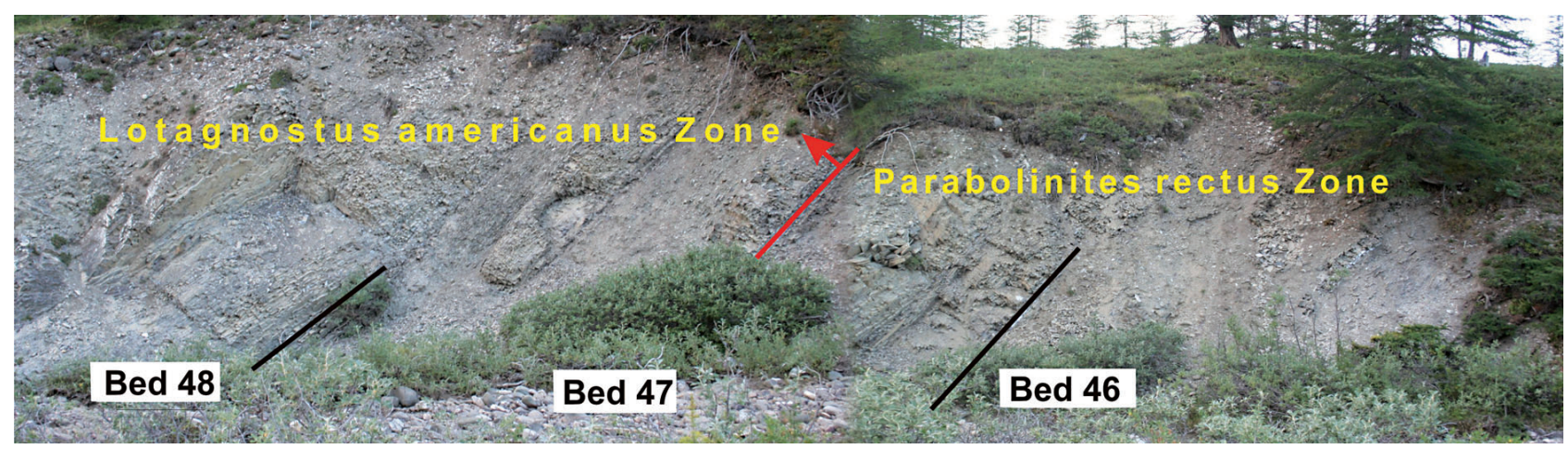

Figure 7. The FAD of Lotagnostus americanus (marked by the red line) at $339 \mathrm{~m}$ above the base of Ogon'or Formation in the Khos-Nelege reference section (from Lazarenko et al. 2008).

previously identified as Lotagnostus hedini (Lazarenko et al. 2008, pl. 21, figs 1, 5; pl. 23, figs 3, 4; Figs 19, 25), should be re-assigned to Lotagnostus (Eolotagnostus) and their closest relative is Lotagnostus (Eolotagnostus) agnostiformis Apollonov \& Chugaeva. These specimens are the first representatives of the genus Lotagnostus in the Ogon' or Formation and they occur at $18 \mathrm{~m}$ below the FAD of L. americanus. In Kazakhstan, Lotagnostus (E.) agnostiformis occurs in the Lotagnostus (Eolotagnostus) scrobicularis-Jegorovaia Biozone (Ergaliev \& Ergaliev 2008). This biozone is of similar age to the Lotagnostus (Eolotagnostus) decorus-Kaolishania Biozone of South China, which is stratigraphically below the Lotagnostus (Lotagnostus) punctatus-Hedinaspis regalis Zone (Peng 1992).

In addition to L. americanus, a number of other biostratigraphically informative trilobite taxa, which are useful for intercontinental correlations, are present near the proposed stage boundary in the Khos-Nelege section (Figs 9, 10). For instance, Trilobagnostus rudis (Salter) occurs at $40 \mathrm{~m}$ above the FAD of Lotagnostus americanus. In Scandinavia, the FAD of this species is documented at the base of the Lotagnostus americanus Biozone (Terfelt et al. 2011). Skljarella cf. marinae Petrunina occurs in the lower half of the Lotagnostus americanus Biozone above the first occurrence of Lotagnostus (E.) agnostiformis. Skljarella marinae Petrunina, first described from the Dobrinskiy Regional Stage of the Altai-Sayan Region. It can be correlated to the lower part of the Batyrbai Regional Stage (uppermost Furongian) of Malyi Karatau in Kazakhstan (Trisulcagnostus trisulcus-Saukiella and Lotagnostus (Eolotagnostus) scrobicularis-Jegorovaia biozones). The genus Eurycarina Ivshin in Petrunina is common in the Zolotokitatskii Regional Stage and sporadically occurs in the Dobrinskii Regional Stage in the Altai-Sayan Region (Petrunina \& Gabova 2008), which is equivalent to the upper part of Aksayan and the lower part of Batyrbaian regional stages in Kazakhstan. In the Ogon'or Formation section, different species of this genus occur below the Lotagnostus americanus Zone. Promegalaspides pelturae and P. kinnekullensis occur at the FAD of Lotagnostus americanus in the Ogon' or Formation, and in Scandinavia they are found within the lower Trilobagnostus holmi Biozone (Terfelt et al. 2011). In the Khos-Nelege section, Macropyge (Aksapyge) transita occurs at $55 \mathrm{~m}$ above the base of the Lotagnostus americanus Biozone. In Kazakhstan, it is widespread in the upper part of the Hedinaspis sulcata Biozone (the upper part of the Aksayan) (Apollonov et al. 1984).

The trilobite assemblage of L. americanus Biozone in Khos-Nelege suggests a close palaeobiogeographic link with Baltica. Taxa in common include Lotagnostus americanus, Trilobagnostus rudis, Promegalaspides kinnekullensis, $P$. pelturae, and representatives of the genera Parabolinites, Parabolinella, Macropyge, and Niobella. Moreover, the presence of Neoagnostus, Ketyna (= Kujandaspis), and Skljarella in this zone indicate clear links with other parts of Siberia, as well as with South Kazakhstan and China.

In the Khos-Nelege section the FAD of $L$. americanus occurs in an interval marked by a distinct change in taxonomic composition of polymerid trilobite fauna (see Fig. 8). At approximately $10 \mathrm{~m}$ below the FAD of $L$. americanus, the species ranging upwards from the Plicatolina perlata Biozone disappear and the first representatives of the genera Skljarella, Westonaspis and Promegalaspides, which is particularly common in the L. americanus Biozone, appear. A similar change has been documented at the base of the Lotagnostus americanus Biozone in Scandinavia. In underlying the Ctenopyge spectabilis Biozone the first representatives of Peltura, Macropyge appear, whereas at the base of $L$. americanus Biozone the first occurrence of Sphaerophthalmus and Parabolinites was reported (Terfelt et al. 2011). In South China Charchaqia, Hedinaspis, Macropyge and Niobella first appear at about the same level (Peng 1992). 


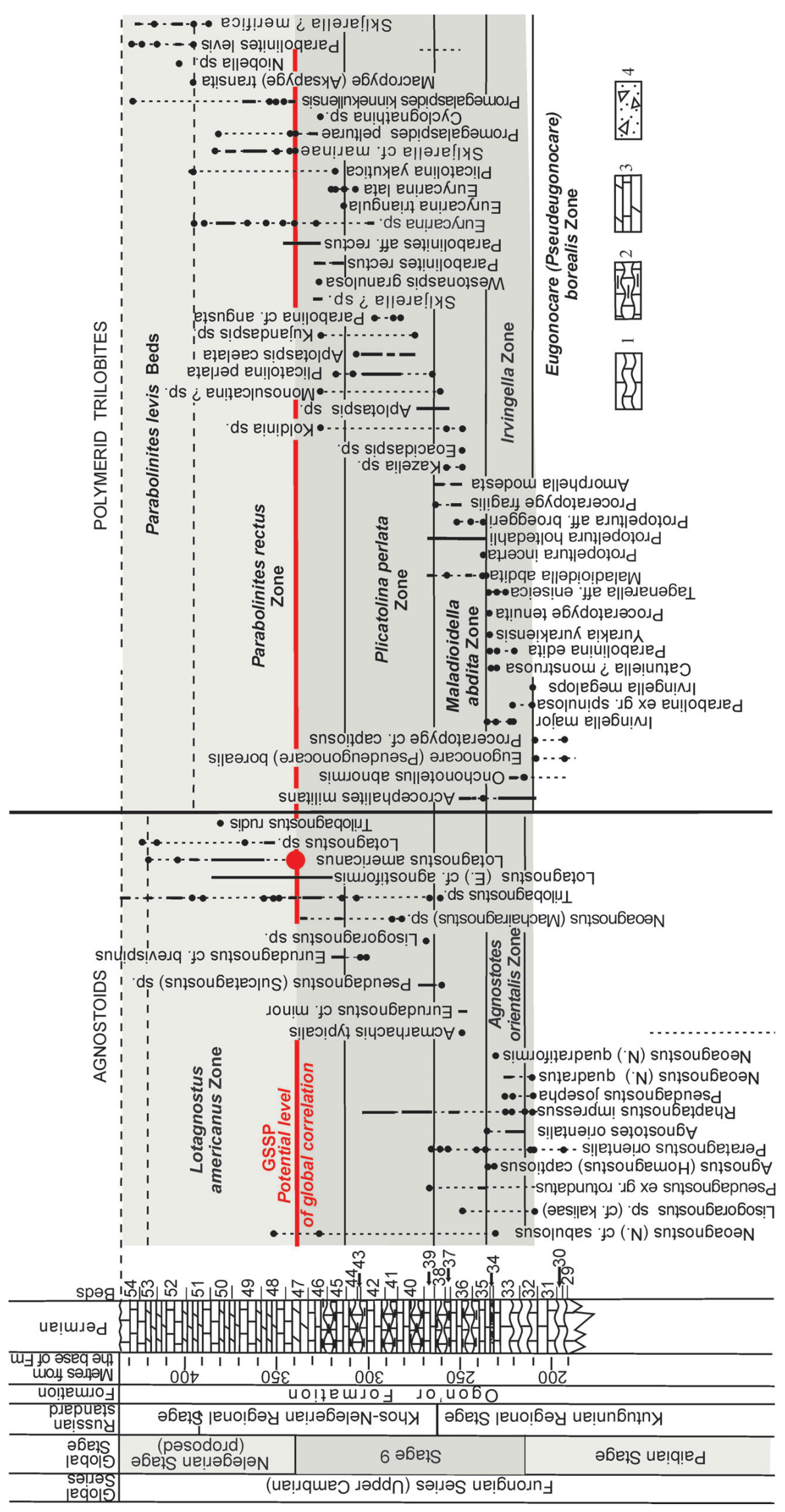

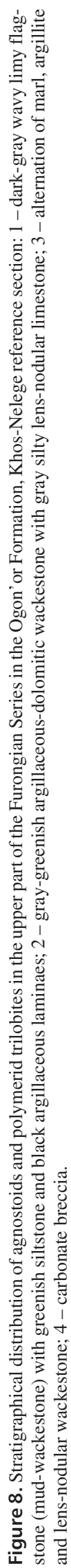



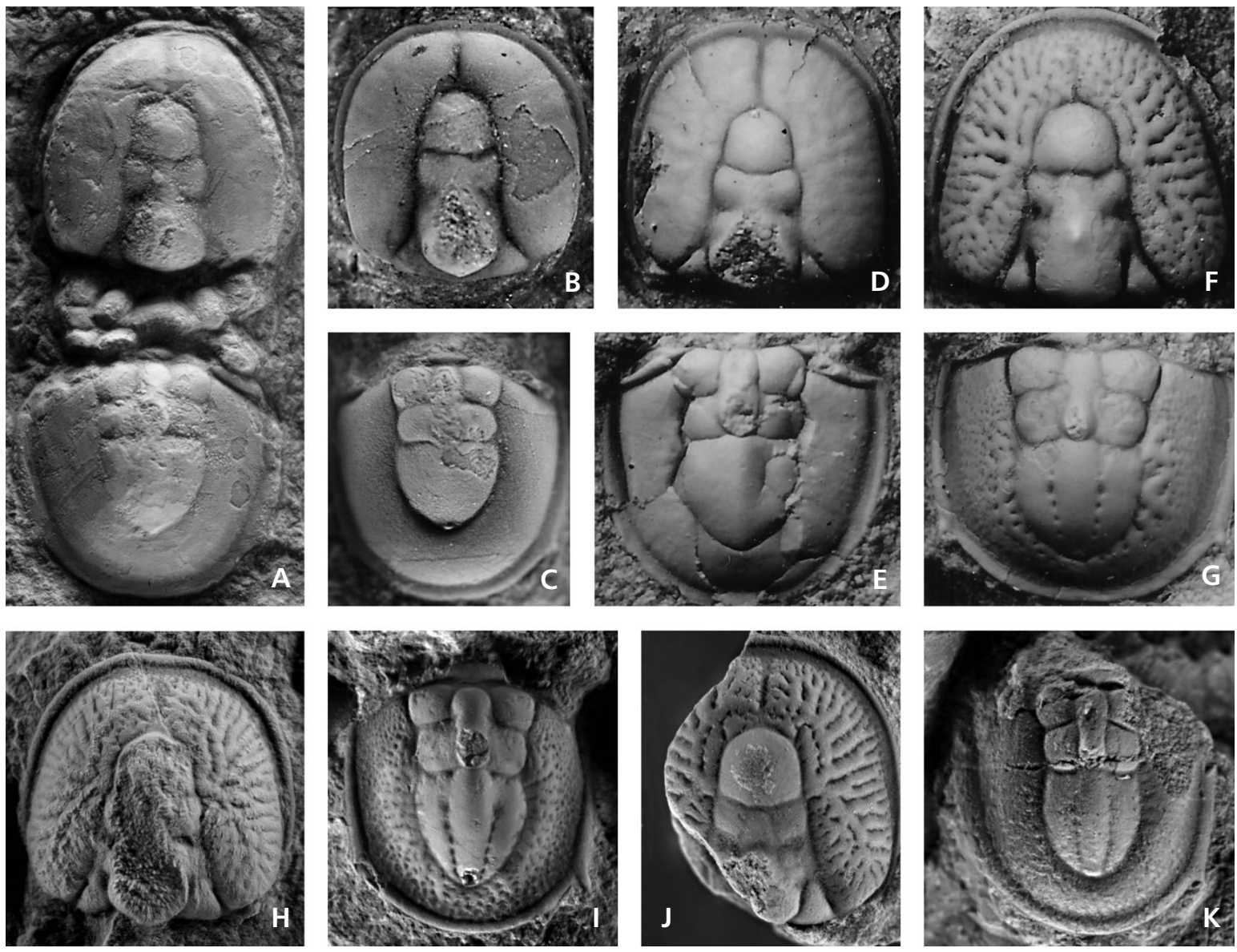

Figure 9. Key species of Lotagnostus used for recognition of the base of the Proposed Stage. All specimens are from the Khos-Nelege section, Western Yakutia, Russia; position of collections in metres (m) above the base of the Ogon' or Formation are indicated. • A-E - Lotagnostus (Eolotagnostus) cf. agnostiformis Apollonov \& Chugaeva: A - exoskeleton, $\times 9.4$, from $322 \mathrm{~m}$; B - cephalon, $\times 20$, from $322 \mathrm{~m}$; C - pygidium, $\times 17.5$, from 322 m; $\mathrm{D}$ - cephalon, $\times 12$, from $335.6 \mathrm{~m}$; E - pygidium, $\times 11$, from $335.6 \mathrm{~m} \cdot \bullet \mathrm{F}-\mathrm{K}-$ Lotagnostus (Lotagnostus) americanus (Billlings): $\mathrm{F}-$ cephalon, $\times 9$, from $357.6 \mathrm{~m}$; G - pygidium, $\times 8$, from $357.6 \mathrm{~m}$; H - cephalon, $\times 6.4$, from $397.5 \mathrm{~m}, \mathrm{I}-$ pygidium, $\times 8$, from $397.5 \mathrm{~m}, \mathrm{~J}-$ cephalon, $\times 7.5$, from $398 \mathrm{~m}$, $\mathrm{K}$ - pygidium, $\times 12.6$, from $427 \mathrm{~m}$.

\section{Conodont biostratigraphy}

Application of conodonts for the Cambrian biostratigraphy is relatively limited and increased only for the upper Furrongian, when euconodonts appeared and diversified. In the Khos-Nelege section the upper part of the Cambrian Stage 9 and the lower part of the Cambrian Stage 10 are characterized by conodont assemblages referred to the Westergaardodina amplicava Biozone (Fig. 11). Most of the conodont taxa first documented from the Cambrian Stage 9, including Westergaardodina bohlini, W. amplicava, W. tricuspidata, C. bicostatus, Prooneotodus rotundatus, Prosagittodontus dunderbergiae, P. minutus, Problematoconites perforatus, Prooneotodus gallatini, Laiwugnathus laiwuensis expanses, are transitional into the Cambrian Stage 10. Conodont assemblage of the Cambrian Stage 10 includes also Westergaardodina cf. procera, W. cf. wimani, Viirodus sp., Muellerodus sp., Furnishina ovata, F. bicarinata, F. cf. alata, Bengtsonella triangularis, Proacontiodus multicostatus,
Phakelodus tenuis. This conodont assemblage shows distinct similarity to the assemblage characteristic of the Westergaardodina amplicava Biozone (the upper part of the Aksai Regional Stage, the Hedinaspis sulcata Trilobite Biozone) in the Batyrbai section of Malyi Karatau (Dubinina 2000). In Malyi Karatau, Kazakhstan, the first occurrence of euconodont is documented only from the base of overlying Batyrbai Regional Stage (Dubinina 2000), whereas they are not yet found in the Khos-Nelege section.

\section{Brachiopod biostratigraphy}

Brachiopods are present in the Khos-River section but they are rare, have long stratigraphic ranges and are known only from preliminary identifications. Only Quadrisonia minor and Quadrisonia sp. yet documented from the Ogon'or Formation, but they have long stratigraphical ranges and are considered here as biostratigraphically uninformative. 

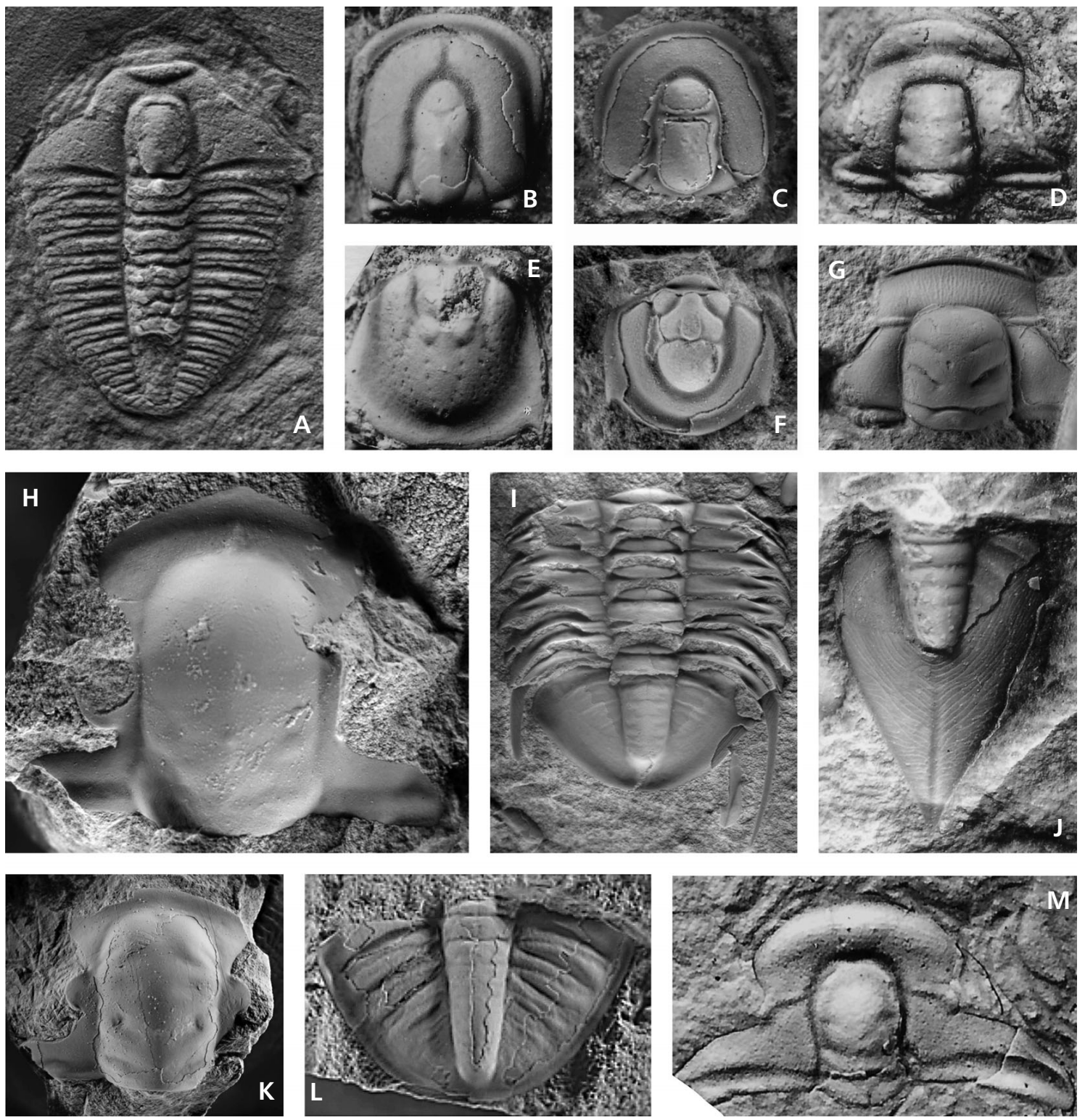

Figure 10. Key agnostoids and polymerid trilobites used for recognition of the base of the Proposed Stage. All specimens are from the Khos-Nelege section, Western Yakutia, Russia; position of collections in metres $(\mathrm{m})$ above the base of the Ogon' or Formation are indicated. $\bullet$ A - Eurycarina triangula Lazarenko \& Pegel, exoskeleton, $\times 14$, from $313.6 \mathrm{~m}$. B, E - Neoagnostus $\mathrm{cf}$. sabulosus Peng: B - cephalon, $\times 9.7$, from $327 \mathrm{~m}$; E - pygidium, $\times 9$, from $327 \mathrm{~m} . \bullet \mathrm{C}, \mathrm{F}-$ Trilobagnostus rudis (Salter): C - cephalon, $\times 14$, from $381 \mathrm{~m} ; \mathrm{F}$ - pygidium, $\times 9$, from $381 \mathrm{~m}$. $\bullet \mathrm{D}-$ Kujandaspis sp., cranidium, $\times 12$, from $327 \mathrm{~m} . \bullet \mathrm{G}-$ Parabolinites levis Lazarenko, cranidium, $\times 6.6$, from $398 \mathrm{~m} \cdot \bullet \mathrm{H}, \mathrm{I}-$ Promegalaspides pelturae Westergård: $\mathrm{H}-$ cranidium, $\times 6.8$, from $382 \mathrm{~m}$; I-thorax and pygidium, $\times 2.6$, from $382 \mathrm{~m}$. $\bullet \mathrm{J}-$ Macropyge (Aksapyge) transita Apollonov \& Chugaeva, latex cast from the imprint of pygidium, $\times 7$, from $395 \mathrm{~m} . \cdot \mathrm{K}, \mathrm{L}-$ Promegalaspides kinnekullensis Westergård: K - cranidium, $\times 3.4$, from $339 \mathrm{~m}$; L - pygidium, $\times 4.5$, from $430.5 \mathrm{~m}$. $\cdot \mathrm{M}-$ Skljarella cf. marinae Petrunina, cranidium, $\times 11.8$, from $364 \mathrm{~m}$.

\section{Chemostratigraphy}

The FAD of Lotagnostus americanus is not marked by a distinctive shift in carbon isotope values, although its position can be broadly recognized within a longer sequence of $\delta^{13} \mathrm{C}$ values (Fig. 12). The FAD of $L$. americanus and the base of the proposed Nelegerian Stage is placed in a field of positive $\delta^{13} \mathrm{C}$ values, which shows a gradual increase from
$+0.25 \%$ to $+1.25 \%$. Strata in the upper part of the underlying Cambrian Stage 9 reach a minimum values of $-0.25 \%$. A small positive shift, which peaks at about $+0.5 \%$, is near the base of the Cambrian Stage 10. This is followed by small oscillations in the $\delta^{13} \mathrm{C}$ curve through the overlying Cambrian Stage 10 with values ranging between $+0.25 \%$ o and $+1.25 \%$. The most distinct position in the Furongian $\delta^{13} \mathrm{C}$ curve is the onset of the SPICE excursion, one of the 


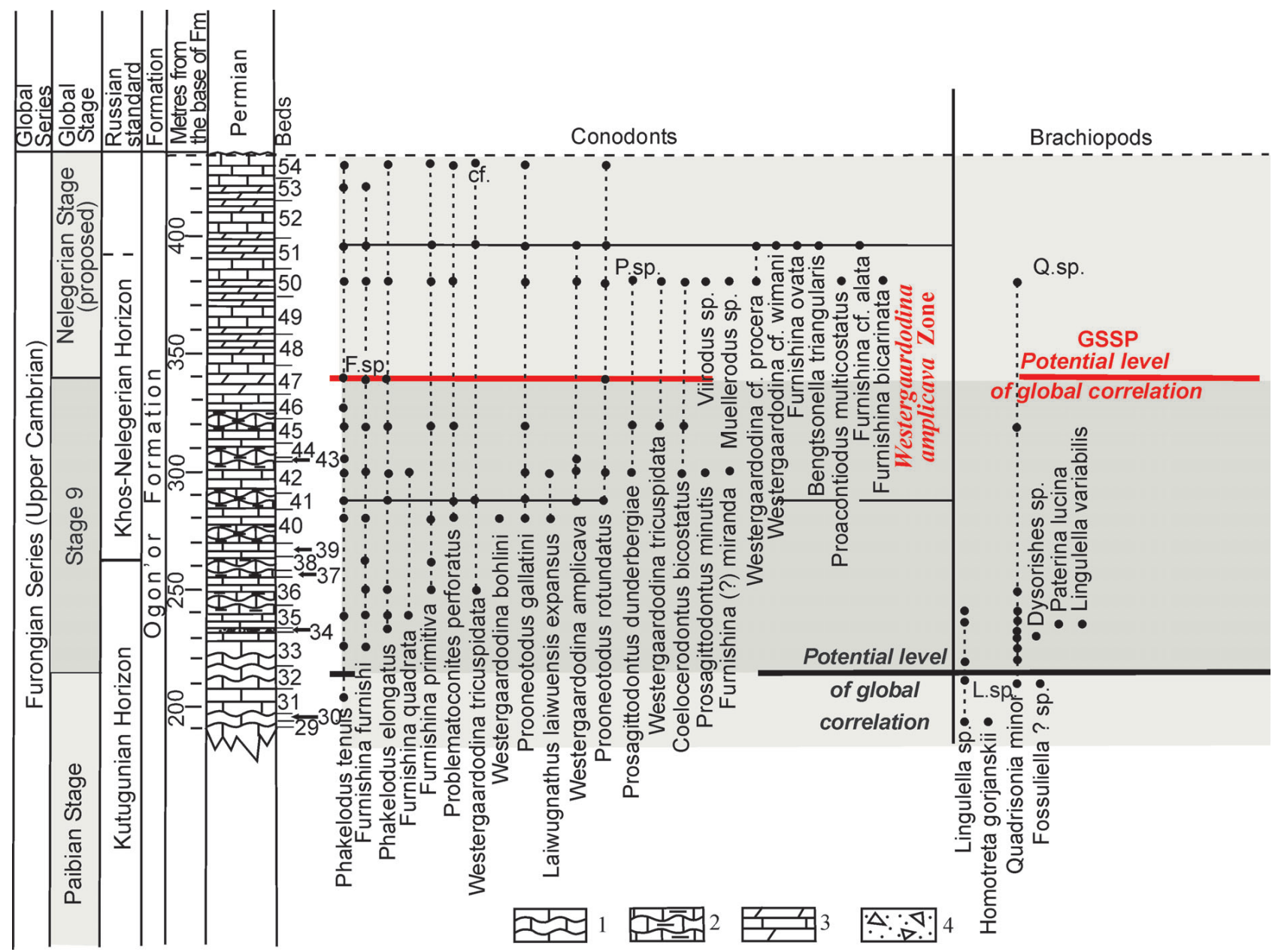

Figure 11. Stratigraphic distribution of conodonts and brachiopods in the upper part of the Furongian Series in the Ogon' or Formation, Khos-Nelege reference section. 1 - dark-gray wavy limy flagstone (mud-wackestone) with greenish siltstone and black argillaceous laminaes; 2 - gray-greenish argillaceous-dolomitic wackestone with gray silty lens-nodular limestone; 3 - alternation of marl, argillite and lens-nodular wackestone; 4 - carbonate breccia.

largest positive $\delta^{13} \mathrm{C}$ excursions known from the Lower $\mathrm{Pa}$ leozoic. In the proposed section of the Khos-Nelege it reaches peak values of about $+4.5 \%$ and is located within the upper third of the Paibian Stage (about the middle of the Eugonocare (Pseudeugonocare) borealis Biozone) below the FAD of trilobites Irvingella and Agnostotes orientalis.

\section{Sequence stratigraphy}

Cambrian strata exposed along the Khos-Nelege section were mainly deposited in a deep-water, middle to distal slope environment setting stable for a substantial amount of time (see Fig. 12). Therefore, developmental phases of the sedimentary basin are not easily distinguishable in comparison with relatively shallow-water shelf successions. Deposition of the Ogon' or Formation took place well below storm wave base and there were no any significant change of lithofacies, submarine erosion or non-deposition caused by sea level fluctuations of eustatic or tectonic nature. The lower part of the Ogon' or Formation displays lithofacies transitional from an outer-fan fringe to outer-fan lobe, which was followed by gradual progradation of the slope during the rest of the late Cambrian.

\section{Other regional sections and reasons for rejection}

Lotagnostus americanus has been documented from a number of section in various parts of Siberia. Some of them are potentially useful for definition of the FAD of Lotagnostus americanus. In particular these include (1) the section of the Stepanovo Formation in the Trautfetter River basin, the south-western Taimyr Peninsula (Sobolevskaya et al. 1995), and (2) the section of the Dzhunyukan and Billyakh formations exposed along the Dzhunyukan River in Southern Verkhoyanie (Gogin 2009). However, these 

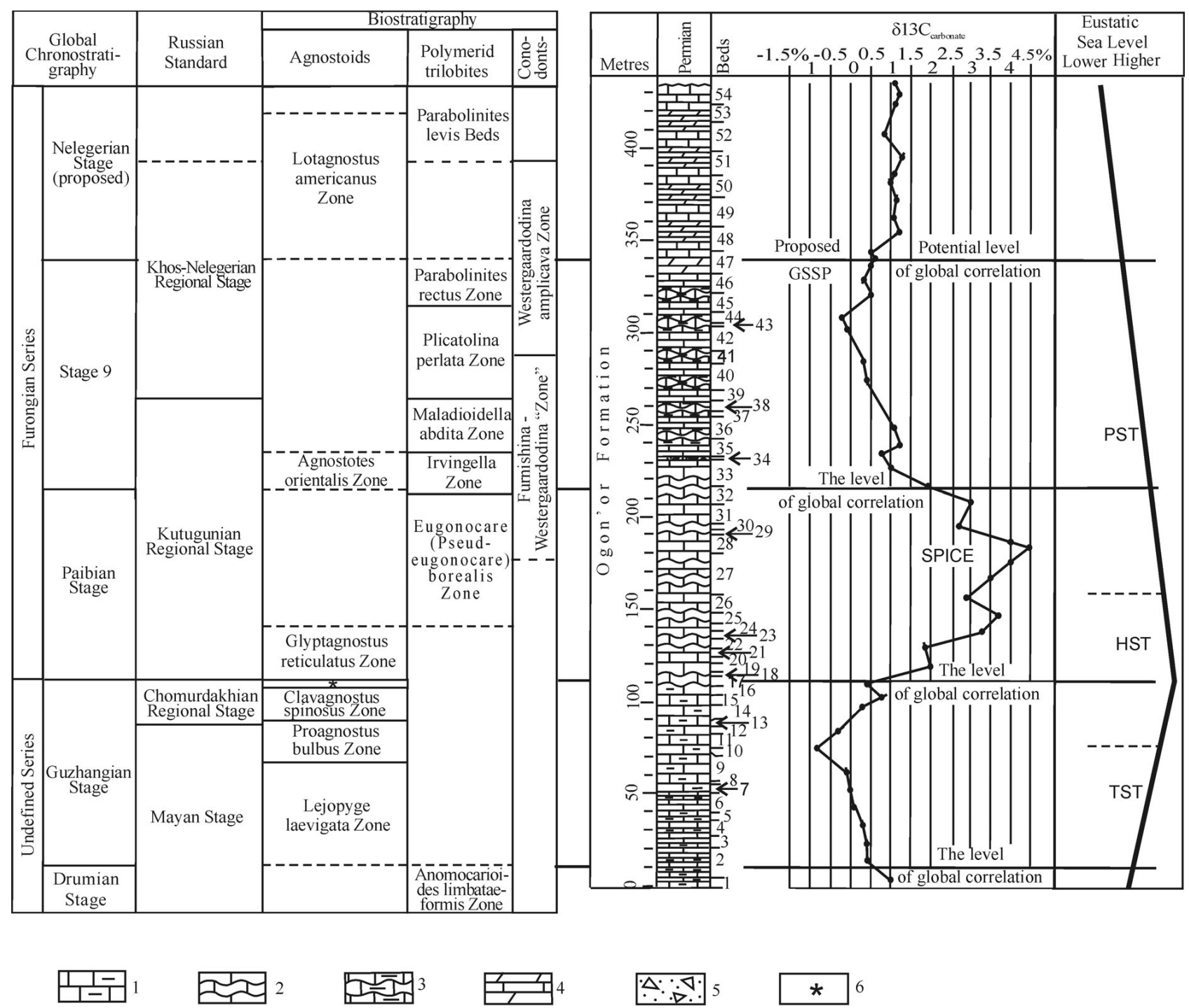

Figure 12. Summary of primary and secondary stratigraphic indicators for the base of the proposed Nelegerian Stage of the Cambrian System (modified from Lazarenko et al. 2008). 1 - alternation of dark-gray laminated mudstone to shale, with minor thin chert and pyrite, greenish terrigenious-carbonate siltstone and distal carbonate turbidite; 2 - dark-gray wavy limy flagstone (mud-wackestone) with greenish siltstone and black argillaceous laminas; 3 - greenish-gray argillaceous-dolomitic wackestone with gray silty lens-nodular limestone; 4 - alternation of marl, argillite and lens-nodular wackestone; 5 - carbonate breccia; 6 - Glyptagnostus stolidotus Zone.

sections are stratigraphically less complete and existing data on palaeontology and stratigraphy need to be upgraded to make them competitive candidates for the Cambrian Stage 10 GSSP definition.

\section{Other extraregional sections}

There are several Cambrian (Furongian) sections in Sweden and in South China, which can be considered as potential candidates for Cambrian Stage 10 GSSP defined by the FAD of L. americanus (Terfelt et al. 2008, Lu \& Lin 1989, Peng 1992). However the upper Furongian sequence in Sweden (Scania) is poor in agnostoids whereas accompa- nying complexes of polymerid trilobites are largely endemic, or have limited geographical distribution.

The Duibian B section in a vicinity if the Duibian village, Jiangshan County, Zhejiang Province, China (Peng et al. 2009) has been voted by the ISCS as the GSSP for the Cambrian Stage 9. The adjacent profile, called the Duibian A section, exhibits one of the most complete Cambrian sequences in western Zhejiang, comprising strata, which extend from the Ediacaran to the Ordovician. It is located approximately $9 \mathrm{~km}$ north-east of the city of Jiangshan and was one of the candidate stratotype sections proposed for the base of the Ordovician (Peng et al. 2009). The Siyanshan Formation at the top of the Duibian A section is a highly fossiliferous unit rich in polymerids and 
agnostoids. Lotagnostus americanus appears at the base of the Formation and in the upper $3 \mathrm{~m}$ contain Lotagnostus hedini in abundance, where it occurs together with the conodont Cordylodus proavus (Lu \& Lin 1989). This section is inferior to the Khos-Nelege section as the Cambrian Stage 10 GSSP candidate, because the rocks underlying the FAD of L. americanus are poorly fossiliferous (only two horizons with Macropyge longa and Pseudagnostus josepha, respectively are indicated). Furthermore, the appearance of $L$. americanus coincides with a sedimentary change, suggesting an environmental change and possible biofacies shift (Peng et al. 2005, 2009).

\section{The alternative proposals for global correlation levels defining the base of the upper stage of the Cambrian}

Besides trilobites, several conodont levels have been suggested as possible markers to define the base of the Cambrian Stage 10. In particular, Miller et al. (2005) suggested the Lawson Cove section (Utah, USA) as the terminal Cambrian Stage GSSP candidate. The proposed horizon coincides with the FAD of Cordylodus andresi Viira and Sergeeva at the base of the Cordylodus proavus Biozone. Recently, Landing et al. (2010) proposed the level of the FAD of Eoconodontus notchpeakensis as the primary correlation point for the base of the Cambrian Stage 10 and suggested the Lawson Cove section as a potential stratotype.

Eoconodontus notchpeakensis occurs in the Dobryi Regional Stage of the Altai-Sayany Region and its FAD is recorded in the Loparian Regional Stage of the Kulumbe River (Siberian Platform) reference section, which exposes a typical inner-shelf sequence. Endemic species of trilobites Dolgeuloma and Saukiella are also present in these deposits. Reviews by Abaimova and Tolmacheva (Abaimova et al. 2008, Tolmacheva \& Abaimova 2009) suggest that a part of the Mansian Regional Stage, the Loparian and the lower part of the Nyaian Regional Stages of the Siberian Platform can be correlated with the E. notchpeakensis Biozone. E. notchpeakensis is still unknown in the basinal settings around Siberia.

Dubinina (2009) suggested the Batyrbai section in Malyi Karatau (South Kazakhstan) as a potential GSSP of the Cambrian Stage 10 defined by the FAD of the conodont Cordylodus proavus. This species is geographically widespread and is found in all major Cambrian continents. On the Siberian Platform it is recorded only in inner-shelf sequences of the upper part of the Loparian Regional Stage close to the base of the Nyaian Regional Stage. Cordylodus proavus is accompanied here by the polymerids Plethopeltides magnus, Nyaya nyaensis, and Eoapatokephalus nyaicus. A precise trilobite based correlation with basinal sequences across Siberia within this interval proved difficult.

\section{Conclusions}

The Khos-Nelege section of the Ogon' or Formation at the Kharaulakh Mountains, Western Yakutia, Russia, is proposed as a candidate stratotype for the GSSP of Cambrian Stage 10, which is defined by the FAD of the agnostoid Lotagnostus americanus. The proposed name of the stage is Nelegerian after the Neleger River.

The proposed GSSP is at $339 \mathrm{~m}$ above the base of the Ogon'or Formation in the Khos-Nelege section. It fulfills all biostratigraphical, chemostratigraphical, paleogeographic, facies-relationship, and sequence stratigraphy requirements for the GSSP (Remane et al. 1996).

Nelegerian Stage is here proposed to be the uppermost of the three stages (Stage 10) of the Furongian Series of the Cambrian System.

\section{Acknowledgements}

We are greatly indebted to the referee F. Terfelt, Lund University, Sweden, for comments and reviewing an earlier version of this report. His critical remarks and advice were very helpful. Extremely useful were comments and suggestions of L. Popov, National Museum Cardiff, Wales, UK, whose considerable skills have been used for producing the final versions of this manuscript.

\section{References}

Abaimova, G.P., Tolmacheva, T.Y. \& Komlev, D.A. 2008. New data on Upper Cambrian and Lower Ordovician conodonts from the Loparian and Nyaian regional stages on the Kulumbe River section, north-west of the Siberian Platform, 3-5. In Proceedings of an international conference on Development of Early Paleozoic biodiversity: role of biotic and abiotic factors, and event correlation. KMK Scientific Press Ltd., Moscow.

AhlberG, P. 2003. Trilobites and intercontinental tie points in the Upper Cambrian of Scandinavia. Geologica Acta 1(1), 127-134.

Ahlberg, P. \& AHLgRen, J. 1996. Agnostoids from the Upper Cambrian of Västergötland, Sweden. Geologiska Föreningens i Stockholm Förhandlingar (GFF) 118, 129-140.

Apollonov, M.K. \& Chugaeva, M.N. 1983. The problem of the Cambrian and Ordovician boundary, 16-25. In APOLLONOV, M.K., BANDALETOV, S.M \& IVSHIN, N.K. (eds) The Lower Paleozoic stratigraphy and paleontology of Kazakhstan. Nauka, Alma-Ata. [in Russian]

Apollonov, M.K. \& Chugaeva, M.N. \& Dubinina, S.V. 1984. Trilobites and conodonts from the Batyrbay section (Uppermost Cambrian-Lower Ordovician) in Malyi Karatau Range (atlas of the palaeontological plates). 48 pp. Nauka, Alma-Ata. [in Russian]

BAbcock, L.E., Peng, S.C., Geyer, G. \& Shergold, J.H. 2005. Changing perspectives on Cambrian chronostratigraphy 
and progress toward subdivision of the Cambrian System. Geosciences Journal 9(2), 101-106.

BILLINGS, E. 1860. On some new species of fossils from the limestone near Point Levi, opposite Quebec. Canadian Naturalist and Geologist 5, 301-324.

BORDONARO, O.L. 1985. El género Lotagnostus (Trilobita, Agnostoida) en el Cámbrico Superior de Mendoza, 17-19. Reunión de Comunicaciones Paleontológicas. Asociación Paleontológica Argentina, San Juan.

DUBININA, S.V. 2000. Conodonts and zonal stratigraphy of the Cambrian-Ordovician boundary deposits. 237 pp. Nauka, Moscow. [in Russian]

Dubinina, S. 2009. Proposed new terminal stage of the Cambrian system in Kazakhstan, 18-19. In ERGALIEV, G.K., NiKitinA, O.I., ZHEMCHUZHNIKOV, V.G., POPOV, L.E. \& BASSET, M.G. (eds) Materials of the $14^{\text {th }}$ International Field Conference and Excursions of the Cambrian stage subdivision Working group. Almaty - Malyi Karatau Ridge, South Kazakhstan. Gylym, Almaty.

ERGALIEV, G.K. 1983. The Cambrian and Ordovician boundary in Southern Kazakhstan and Ulutau, 6-16. In APOLLONOV, M.K, BANDALETOV, S.M. \& IVshin, N.K. (eds) The Lower Paleozoic stratigraphy and paleontology of Kazakhstan. Nauka, Alma-Ata. [in Russian]

ERGaliEV, G.K. \& ERGAliEV, F.G. 2008. Middle and Upper Cambrian Agnostoida of the Aksai National Geological Reserve South Kazakhstan (Kyrshabakty River, Malyi Karatau Range). Part 1.376 pp. Gylym, Almaty. [in Russian]

GEYER, G. \& SHERGOLD, J.H. 2000. The quest for internationally recognized divisions of Cambrian time. Episodes 23(3), $188-195$.

Gogin, I.Y. 2009. Chart Cambrian deposits of Northeast of Russia, 37-52. In KoreN', T.N. \& KOTLJAR, G.V. (eds) Decision of the Third interdepartmental stratigraphy meetings on Precambrian, Paleozoic and Mesozoic Northeast of Russia (St.-Petersburg, 2002). VSEGEI Press, St. Petersburg. [in Russian]

HUTCHINSON, R.D. 1952. The stratigraphy and trilobite faunas of the Cambrian sedimentary rocks of Cape Breton Island, Nova Scotia. Geological Survey of Canada Memoir 263, 1-124.

LANDING, E., WESTROP, S.R. \& MiLLER, J.F. 2010. Global practical base for the uppermost Cambrian (Stage 10) - FAD of the conodont Eoconodontus notchpeakensis and the Lawsonian Stage, 18. In FATKA, O. \& BUDIL, P. (eds) The $15^{\text {th }}$ Field Conference of the Cambrian Stage Subdivision Working Group, International Subcommission on Cambrian Stratigraphy. Abstracts and Excursion Guide, Prague, Czech Republic and south-eastern Germany. Czech Geological Survey, Prague.

LAZARENKO, N.P. 1966. Upper Cambrian biostratigraphy and some new trilobites from the Olenek Uplift and Kharaulakh Mountains, 33-78. In SHVEDOV, N.A. (ed.) Scientific notes of the Scientific-Research Institute of Geology of Arctic. Palaeontology and biostratigraphy 11. Scientific-Research Institute of Arctic Geology Press, Leningrad. [in Russian]

LAZARENKO, N.P. 1973. Middle and Upper Cambrian strata of north-central Siberia. American Association of Petroleum Geologists Memoirs 19, 291-295.

LaZarenko, N.P., Gogin, I.Y., Pegel, T.V., Sukhov, S.S., Abaimova, G.P., Egorova, L.I., Fedorov, A.B., RAEV-
SKAYA, E.G. \& USHATINSKAYA, G.T. 2008. Excursion 1b. Cambrian stratigraphy of the northeastern Siberian Platform and potential stratotypes of lower boundaries of the proposed Upper Cambrian Chekurovian and Nelegerian stages in the Ogon'or Formation section at the Khos-Nelege River; the boundaries are defined by the FADs of Agnostotes orientalis and Lotagnostus americanus, 60-139. In ROZANOV, A.Y. \& VARLAMOV, A.I. (eds) The Cambrian System of the Siberian Platform. Part 2: North-east of the Siberian Platform. PIN RAS, Moscow \& Novosibirsk.

LAZARENKO, N.P. \& NIKIFOROV, N.I. 1972. Middle and Upper Cambrian of northern Siberian Platform and adjacent folded regions, 4-17. In BONDAREV, V.I. \& RABKINA, M.I. (eds) Stratigraphy, Palaeogeography and Commercial Minerals of the Soviet Arctic. Scientific-Research Institute of Arctic Geology Press, Leningrad. [in Russian]

LAZARENKO, N.P. \& Pegel, T.V. 2001. Upper Cambrian levels of biostratigraphical correlation in the Khos-Nelege River reference section (northeastern flank of the Siberian Platform). Palaeoworld 13, 276-279.

LIN, T. 1986. A late Upper Cambrian trilobite fauna from Northwestern Jiangxi. Journal of Nanjing University (Natural Sciences) 22(1), 129-146. [in Chinese with English abstract]

LISOGOR, K.A. 1977. Upper Cambrian and Tremadocian biostratigraphy and trilobites of the Malyi Karatau (Southern Kazakhstan), 197-265. In ZHURAVLEVA, I.T. \& ROSOVA, A.V. (eds) Biostratigraphy and fauna of the Upper Cambrian and its boundary layers. Nauka, Novosibirsk. [in Russian]

LU, Y.H., Chang, W.T., ChU, C.L., ChIEN, Y.Y. \& HSIANG, L.W. 1965. Chinese fossils of all groups. Trilobites of China 1, 2. 766 pp. Science Press, Bejing. [in Chinese]

LU, Y.H. \& LIN, H.L. 1980. Cambro-Ordovician boundary in Western Zhejiang and the trilobites contained therein. Acta Palaeontologica Sinica 19(2), 118-135. [in Chinese with English abstract]

LU, Y.H. \& LIN, H.L. 1983. Zonation and correlation of Cambrian Faunas in W. Zheijang. Acta Geologica Sinica 57, 317-328. [in Chinese with English abstract]

LU, Y.H. \& LIN, H.L. 1984. Late Cambrian and earliest Ordovician trilobites of Jiangshan-Changshan area, Zhejiang, 45-143. In NANJING INSTITUTE OF GEOLOGY AND PALEONTOLOGY, ACADEMIA SINICA (ed.) Stratigraphy and Palaeontology of Systemic Boundaries in China, Cambrian-Ordovician Boundary 1. Anhui Science and Technology Publishing House, Hefei.

LudVigSEN, R., WeSTROP, S.R. \& KindLE, C.H. 1989. Sunwaptan (Upper Cambrian) trilobites of the Cow Head Group, western Newfoundland, Canada. Palaeontographica Canadiana $6,1-175$.

MilleR, J.F., EvAns, K.R., Ethington, R.R., HolmeR, L.E., LOCH, J.D., POPOV, L.E. \& RIPPERDAN, R.L. 2005. GSSP candidate for the base of the highest Cambrian stage at Lawson Cove, Utah, USA. Acta Micropalaeontologica Sinica 22 (Supplement), 115-116.

MÜLlER, K.J. \& HINZ, I. 1991. Upper Cambrian conodonts from Sweden. Fossils and Strata 28, 1-153.

ÖPIK, A.A. 1963. Early Upper Cambrian fossils from Queensland. Bulletin - Australia Bureau of Mineral Resources 64, $1-133$. 
PALMER, A.R. 1965. Trilobites of the Late Cambrian Pterocephaliid Biomere in the Great Basin, United States. U.S. Geological Survey Professional Paper 493, 1-105.

PenG, S. 1984. Cambrian-Ordovician boundary in the CiliTaoyuan border area, northwestern Hunan with descriptions of relative trilobites, 285-405. In NANJING INSTITUTE OF GEOlOGY AND PALEONTOlogy, ACADEMIA SiniCa (ed.) Stratigraphy and Palaeontology of Systemic Boundaries in China, Cambrian-Ordovician Boundary 1. Anhui Science and Technology Publishing House, Hefei.

PENG, S.C. 1990. Upper Cambrian in the Cili-Taoyuan area, Hunan, and its trilobite succession. Journal of Stratigraphy 14, 261-276.

PENG, S. 1992. Upper Cambrian biostratigraphy and trilobite faunas of the Cili-Taoyuan area, northwestern Hunan, China. Association of Australasian Palaeontologists, Memoir 13, 1-119.

PENG, S. \& BABCOCK, L.E. 2005. Two Cambrian agnostoid trilobites, Agnostotes orientalis (Kobayashi, 1935) and Lotagnostus americanus (Billings, 1860): Key species for defining global stages of the Cambrian System. Geosciences Journal 9(2), 107-115. DOI 10.1007/BF02910573

PenG, S.C., BABCOCK, L.E., Robison, R.A., Lin, H.L., REES, M.N. \& SALTZMAN, M.R. 2004. Global Standard Stratotypesection and Point (GSSP) of the Furongian Series and Paibian Stage (Cambrian). Lethaia 37, 365-379. DOI 10.1080/00241160410002081

PenG, S., BABCOCK, L.E., ZuO, J., LiN, H., ZhU, X., YANG, X., QI, Y., BAGNOLI, G. \& WANG, L. 2009. Proposed GSSP for the base of Cambrian Stage 9, coinciding with the first appearance of Agnostotes orientalis, at Duibian, Zhejang, China. Science in China Series D: Earth Sciences 52(4), 434-451. DOI 10.1007/s11430-009-0045-8

Peng, S., ZuO, J., BABCOCK, L.E., LIN, H., Zhou, C., YANG, X. \& LI, Q. 2005. Cambrian sections at Dadoushan near Duibian, Jiangshan, western Zhejiang and candidate stratotype for the base of an unnamed global stage defined by the FAD of Agnostotes orientalis, 210-227. In PENG, S., BABCOCK, L.E. \& ZHU, M. Cambrian System of China and Korea. Guide to Field Excursion. IV International Symposium on the Cambrian System and X Field Conference of the Cambrian Stage Subdivision Working Group. University of Science and Technology of China Press, Hefei.
PetruninA, Z.E. \& Gabova, M.F. 2008. Upper Cambrian trilobites of the Kuznetsk Alatau and Salair (Ust'-Kul'bich Horizon). 114 pp. In GUTAK, Y.M. (ed.) Paleontology of Kuzbass 1. KuzGPA Publishing House, Novokuznetsk. [in Russian]

RASETTI, F. 1959. Trempealeauian trilobites from the Conococheague, Frederick, and Grove limestone of the Central Appalachians. Journal of Paleontology 33(3), 375-398.

REMANE, J., BASSET, M.G., COWIE, J.W., GOHRBANDT, K.H., LANE, H.R., MichELSEN, O. \& WANG, N.W. 1996. Revised guidelines for the establishment of global chronostratigraphic standards by the International Commission on Stratigraphy (ICS). Episodes 19, 77-81.

SALTER, J.W. 1864. Figures and descriptions illustrative of British organic remains. Decade 11, Trilobites (chiefly Silurian). Memoirs of the Geological Survey of the United Kingdom, $1-64$.

SoboleVskaya, R.F., KABAnKov, V.Y. \& BondareV, V.I. 1995. About boundaries of Ordovician system on Taimyr Peninsula, 113-122. In SAMOILOV, A.G. (ed.) Bowels of Taimyr, Part 1. VSEGEI Press, Norilsk. [in Russian]

Terfelt, F., AHLBERG, P. \& ERIKSSON, M.E. 2011. Furongian polymerid trilobites and agnostoids of Scandinavia. Lethaia 44, 8-14. DOI 10.1111/j.1502-3931.2009.00211.x

Terfelt, F., Eriksson, M.E., AHLBERG, P. \& BABCock, L.E. 2008. Furongian Series (Cambrian) biostratigraphy of Scandinavia - a revision. Norwegian Journal of Geology 88, 73-87.

Tolmacheva, T. \& ABAimova, G. 2009. Late Cambrian and Early Ordovician conodonts from the Kulumbe River section, northwest Siberian Platform. Memoirs of the Association of Australasian Palaeontologists 37, 427-451.

Troedsson, G.T. 1937. On the Cambro-Ordovician faunas of Western Quruq Tagh, Eastern T'ien-shan. Palaeontologia Sinica 106, New Series B 2, 1-74.

WESTERGÅRD, A.H. 1922. Sveriges Olenidskiffer. Sveriges Geologiska Undersökning, Ser. Ca 18, 1-205.

XIANG, L. \& ZHANG, T. 1985. Stratigraphy and trilobite faunas of the Cambrian in the western part of northern Tianshan, Xinjiang. Ministry of Geology and Mineral Resources, Geological Memoirs 2(4), 1-243. [in Chinese with English summary] 